\title{
Osteossíntese com placa bloqueada e cerclagem no tratamento da fratura de ramo mandibular em equino
}

Vinicius Maia Ribeiro Godoy;, Anderson Fernando Souza, Sofia Cicolo Silva, Nicole Fidalgo Paretsis, Julio david Spagnolo, Rodrigo Romero Corrêa, Andre Luiz do Valle de Zoppa

Faculdade de Medicina Veterinária e Zootecnia, Universidade de São Paulo (USP), São Paulo, SP, Brasil

*Autor correspondente

e-mail: vinicius.godoy.usp@gmail.com

\section{Resumo}

As fraturas de mandíbula em equinos são associadas com eventos traumáticos e podem ser desafiadoras para o tratamento cirúrgico em que a instabilidade óssea no foco de fratura pode dificultar a boa evolução do caso. 0 objetivo deste trabalho é descrever um caso de fratura de ramo mandibular, tratado com a combinação de dois métodos de fixação. Uma égua Brasileira de Hipismo, de 2 anos, $409 \mathrm{~kg}$, foi atendida no HOVET-USP. 0 animal havia estirado ao cabresto e, em seguida, foi observado ferimento em região de mandíbula direita. $\mathrm{O}$ tratador notou dificuldade à mastigação de alimento. Após atendimento veterinário na propriedade e exame radiográfico, foi identificada fratura em ramo mandibular direito, no diastema entre os incisivos e pré-molares. 0 animal foi recebido no hospital veterinário 24 horas após a ocorrência da lesão. Foi observada laceração cutânea na face lateral do ramo mandibular direito, com edema e secreção serossanguinolenta. Imagens radiográficas ortogonais revelaram duas linhas de fratura mesiais ao segundo dente pré-molar, com destacamento e deslocamento de fragmento ósseo ventral. Sob anestesia geral inalatória, em decúbito dorsal, realizou-se incisão de $20 \mathrm{cms}$ em região ventral e paralela ao ramo mandibular direito, permitindo o acesso à superfície ventral mandibular. Para correção da fratura, uma placa bloqueada (LCP) foi posicionada, utilizando-a para manter a redução do fragmento destacado. Sete parafusos bloqueados e unicorticais foram usados para a osteossíntese, com dois parafusos rostrais à fratura, um sobre o fragmento destacado e os demais em região distal às linhas de fratura. 0 tecido subcutâneo foi aproximado com fio absorvível sintético e a pele, fechada com agrafes. Realizou-se, ainda, a cerclagem entre os dentes incisivos, com ancoragem entre o segundo e terceiro dentes pré-molares, para aumentar a estabilidade óssea, gerando maior resistência mecânica durante a mastigação. Os fios de cerclagem e os dentes incisivos foram recobertos com resina odontológica para evitar sua separação e a ocorrência de lesões sobre a mucosa oral. A laceração em face lateral mandibular foi desbridada e mantida aberta. A 
recuperação anestésica ocorreu com o animal solto, sob sedação prévia, porque se usado o cabresto, este comprimiria a região operada. 0 paciente foi tratado com penicilina, amicacina e fenilbutazona, além de receber tratamento antiálgico com morfina no período pós-operatório imediato. Notou-se incapacidade para mastigação de volumoso na primeira semana pós-operatória, e o animal foi mantido com concentrado comercial para manutenção, além de alimento volumoso peletizado comercial. A ferida cirúrgica apresentou boa evolução, assim como a ferida em face lateral da mandíbula. Foi realizado controle radiográfico a cada 15 dias, onde a partir do 30 dia notou-se início da consolidação da fratura, além de focos de lise ao redor dos parafusos e da placa, sem aspecto de contaminação. Foi realizada a remoção da placa 60 dias após sua implantação. 0 procedimento foi realizado sob sedação e anestesia regional. A cerclagem foi mantida por mais 30 dias e sua remoção foi realizada sob mesma técnica anestésica. A estabilidade é ponto-chave na adequada consolidação das fraturas, especialmente da mandíbula, o que pode propiciar o rápido retorno à alimentação voluntária. Para tanto, a combinação das técnicas de osteossíntese com placa bloqueada e cerclagem atingiu seus objetivos. A utilização de alimento volumoso peletizado foi fundamental para o período pós-operatório imediato. Apesar de contaminada, não foram observadas complicações sépticas na consolidação da fratura. A proximidade dos parafusos aos elementos dentários poderá trazer futuras complicações ainda não notadas. 0 tecido mole dos dentes em formação é radiolucente e não identificado ao exame radiográfico. As técnicas e protocolos utilizados obtiveram êxito no tratamento, permitindo a adequada consolidação óssea.

Palavras-chave: Fratura. Mandíbula. Osteossíntese. 